\title{
Active surveillance of acute paediatric hospitalisations demonstrates the impact of vaccination programmes and informs vaccine policy in Canada and Australia
}

Karina A Top ${ }^{1,2,3}$, Kristine Macartney3,4,5, Julie A Bettinger ${ }^{6}$, Ben Tan ${ }^{7}$ Christopher C Blyth ${ }^{8}$, Helen S Marshall9, Wendy Vaudry ${ }^{10}$,

Scott A Halperin ${ }^{1,2}$, Peter McIntyre ${ }^{4,5}$, on behalf of the IMPACT and PAEDS investigators ${ }^{11}$

1. Department of Pediatrics, Dalhousie University, Halifax, Canada

2. Canadian Center for Vaccinology, IWK Health Centre, Halifax, Canada

3. These authors contributed equally

4. National Centre for Immunisation Research and Surveillance and The Children's Hospital Westmead, Sydney, Australia

5. Faculty of Medicine and Health, The University of Sydney, Sydney, Australia

6. University of British Columbia and Vaccine Evaluation Center, British Columbia Children's Hospital, Vancouver, Canada

7. University of Saskatchewan, Royal University Hospital, Saskatoon, Canada

8. Telethon Kids Institute and School of Medicine, University of Western Australia and Perth Children's Hospital, Perth, Australia

9. Robinson Research Institute and Adelaide Medical School, The University of Adelaide and VIRTU Women's and Children's Health Network, Adelaide, Australia

10. University of Alberta, Stollery Children's Hospital, Edmonton, Canada

11. The IMPACT and PAEDS investigators are acknowledged at the end of this article

Correspondence: Karina A Top (karina.top@dal.ca), Kristine Macartney (Kristine.macartney@health.nsw.gov.au)

Citation style for this article:

Top Karina A, Macartney Kristine, Bettinger Julie A, Tan Ben, Blyth Christopher C, Marshall Helen S, Vaudry Wendy, Halperin Scott A, Mclntyre Peter , on behalf of the IMPACT and PAEDS investigators. Active surveillance of acute paediatric hospitalisations demonstrates the impact of vaccination programmes and informs vaccine policy in Canada and Australia. Euro Surveill. 2020;25(25):pii=1900562. https://doi.org/10.2807/1560-7917.ES.2020.25.25.1900562

Sentinel surveillance of acute hospitalisations in response to infectious disease emergencies such as the 2009 influenza $A\left(\mathrm{H}_{1} \mathrm{~N}_{1}\right)$ pdmog pandemic is well described, but recognition of its potential to supplement routine public health surveillance and provide scalability for emergency responses has been limited. We summarise the achievements of two national paediatric hospital surveillance networks relevant to vaccine programmes and emerging infectious diseases in Canada (Canadian Immunization Monitoring Program Active; IMPACT from 1991) and Australia (Paediatric Active Enhanced Disease Surveillance; PAEDS from 2007) and discuss opportunities and challenges in applying their model to other contexts. Both networks were established to enhance capacity to measure vaccine preventable disease burden, vaccine programme impact, and safety, with their scope occasionally being increased with emerging infectious diseases' surveillance. Their active surveillance has increased data accuracy and utility for syndromic conditions (e.g. encephalitis), pathogen-specific diseases (e.g. pertussis, rotavirus, influenza), and adverse events following immunisation (e.g. febrile seizure), enabled correlation of biological specimens with clinical context and supported responses to emerging infections (e.g. pandemic influenza, parechovirus, COVID-19). The demonstrated long-term value of continuous, rather than incident-related, operation of these networks in strengthening routine surveillance, bridging research gaps, and providing scalable public health response, supports their applicability to other countries.

\section{Background}

The essential role of hospital-based sentinel surveillance in identifying emerging infections and measuring the incidence of severe disease was highlighted by Thomson and Nicoll in a 2010 editorial in Eurosurveillance referring to surveillance activities in Europe during the 2009 influenza $A\left(\mathrm{H}_{1} \mathrm{~N}_{1}\right)$ pdmo9 pandemic [1]. They argued that given demands on clinicians in disease outbreaks, sentinel hospital-based surveillance needed to be ongoing, allowing it to be augmented, rather than established de novo, in times of crisis [1]. They identified a range of potential roles for sentinel hospital networks in Europe, primarily collection of clinical data, linked to laboratory and epidemiological data, supporting rapid, evidence-based outbreak responses. Beyond outbreak response, hospital networks have been established in low- middleand high-income countries to provide quality data for immunisation programmes, infection control, and seasonal influenza [2-8].

Most hospital-based surveillance networks are focused on specific diseases or syndromic targets. This article analyses the contributions of two active, paediatric hospital-based sentinel networks that, since their inception, have played wide-ranging roles in public health surveillance: the Canadian Immunization Monitoring Program, Active (IMPACT) established in 1991, and the Australian Paediatric Active Enhanced Disease Surveillance (PAEDS) network established in 2007. These networks, which contribute to surveillance 
TABLE 1A

Canadian IMPACT and Australian PAEDS surveillance targets and years of surveillance

\begin{tabular}{|c|c|c|c|}
\hline Target & Years of surveillance & $\begin{array}{l}\text { Integration with other } \\
\text { surveillance systems }\end{array}$ & Funding \\
\hline \multicolumn{4}{|l|}{ AEFIs } \\
\hline \multicolumn{4}{|l|}{ IMPACT (established 1991) } \\
\hline AFP including Guillain-Barré syndrome & 1991-present & \multirow{11}{*}{$\begin{array}{l}\text { Reports to Canadian } \\
\text { Paediatric Surveillance } \\
\text { Program (AFP), Canadian } \\
\text { Adverse Event Following } \\
\text { Immunization Surveillance } \\
\text { System and provincial/ } \\
\text { territorial public health }\end{array}$} & \multirow{11}{*}{ PHAC } \\
\hline Encephalopathy/encephalitis/myelitis & 1991-present & & \\
\hline Bell's palsy & 1991-present & & \\
\hline Seizure & 1991-present & & \\
\hline Hypotonic hyporesponsive episode & $1991-2012$ & & \\
\hline Thrombocytopaenia & 1991-present & & \\
\hline Injection site reactions (cellulitis, abscess) & 1991-present & & \\
\hline Complications of vaccination & 2013-present & & \\
\hline Intussusception & 2009-present & & \\
\hline Varicella vaccine reactivation illness & 2013-present & & \\
\hline $\begin{array}{l}\text { Other reportable AEFIs identified while searching } \\
\text { for the above (e.g. anaphylaxis) }\end{array}$ & 1991-present & & \\
\hline \multicolumn{4}{|l|}{ PAEDS (established 2007) } \\
\hline AFP including Guillain-Barré syndrome & 2007-present & $\begin{array}{c}\text { Communicable Diseases } \\
\text { Network of Australia's polio } \\
\text { expert panel AEFI captured } \\
\text { as part of AFP surveillance } \\
\text { (see below) }\end{array}$ & \multirow{3}{*}{$\begin{array}{l}\text { Commonwealth state/ } \\
\text { territory governments }\end{array}$} \\
\hline Severe acute neurological events & 2013-present & \multirow{3}{*}{$\begin{array}{c}\text { Commonwealth government } \\
\text { (Office of Health Protection) } \\
\text { and state/territory } \\
\text { governments }\end{array}$} & \\
\hline Intussusception & 2007-present & & \\
\hline Seizures & $\begin{array}{l}\text { Infant seizures: } 2007-2008 \\
\text { Febrile seizures: } 2013-2014\end{array}$ & & NHMRC \\
\hline \multicolumn{4}{|l|}{ VACCINE-PREVENTABLE DISEASES } \\
\hline \multicolumn{4}{|l|}{ IMPACT } \\
\hline Pertussis & 1991-present ${ }^{\mathrm{a}}$ & \multirow{4}{*}{ Complements CNDSS } & \multirow{5}{*}{ PHAC } \\
\hline Invasive Haemophilus influenzae disease & $\begin{array}{c}\text { Type b: } 1991-\text { present } \\
\text { All types: } 2007 \text {-present }\end{array}$ & & \\
\hline Congenital rubella syndrome & $1991-1998$ & & \\
\hline Varicella zoster & 2000-present & & \\
\hline Influenza & 2004-present & $\begin{array}{l}\text { Reports to national } \\
\text { FluWATCH system }\end{array}$ & \\
\hline Invasive pneumococcal disease & 1991-present & Complements CNDSS & $\begin{array}{l}\text { Industry funded 1999- } \\
\text { 2004; currently funded by } \\
\text { PHAC }\end{array}$ \\
\hline Invasive meningococcal disease & 2002-present & Complements CNDSS & Industry funded \\
\hline Rotavirus & $2005-2019$ & $\begin{array}{l}\text { No existing public health } \\
\text { surveillance }\end{array}$ & Industry funded \\
\hline \multicolumn{4}{|l|}{ PAEDS } \\
\hline Varicella and zoster & 2007-present & $\begin{array}{l}\text { No nationally consistent } \\
\text { surveillance }\end{array}$ & $\begin{array}{l}\text { Commonwealth and state } \\
\text { governments }\end{array}$ \\
\hline Influenza & 20092014 -present & Reports via FluCAN & $\begin{array}{c}\text { Commonwealth government } \\
\text { NHMRC }\end{array}$ \\
\hline
\end{tabular}


Canadian IMPACT and Australian PAEDS surveillance targets and years of surveillance

\begin{tabular}{|c|c|c|c|}
\hline Target & Years of surveillance & $\begin{array}{l}\text { Integration with other } \\
\text { surveillance systems }\end{array}$ & Funding \\
\hline Pertussis Invasive meningococcal disease & 2012-present 2015-present & $\begin{array}{c}\text { Complements national } \\
\text { dataset National Neisseria } \\
\text { Network }\end{array}$ & NHMRC State governments \\
\hline COVID-19 and PIMS-TS & 2020-present & $\begin{array}{l}\text { Rapidly activated; COVID-19 } \\
\text { reports via FluCAN }\end{array}$ & $\begin{array}{c}\text { Commonwealth and state } \\
\text { governments }\end{array}$ \\
\hline \multicolumn{4}{|l|}{ OTHER } \\
\hline \multicolumn{4}{|l|}{ IMPACT } \\
\hline Respiratory syncytial virus & $2017-2020$ & $\begin{array}{l}\text { No existing public health } \\
\text { surveillance }\end{array}$ & PHAC \\
\hline \multicolumn{4}{|l|}{ PAEDS } \\
\hline Acute encephalitis ${ }^{b}$ & 2013-present & \multirow{4}{*}{$\begin{array}{l}\text { Commonwealth government } \\
\text { (Office of Health Protection) } \\
\text { state/territory governments }\end{array}$} & \multirow{4}{*}{$\begin{array}{l}\text { Investigator funded } \\
\text { Commonwealth and state/ } \\
\text { territory governments } \\
\text { NHMRC }\end{array}$} \\
\hline Respiratory syncytial virus ${ }^{b}$ & Pilot study 1 site, 2018 & & \\
\hline Invasive group A streptococcal disease ${ }^{\mathrm{b}}$ & $\begin{array}{l}\text { Pilot study multiple sites, } \\
2018\end{array}$ & & \\
\hline Kawasaki disease & 2018-present & & \\
\hline
\end{tabular}

AEFI: adverse events following immunisation; AFP: acute flaccid paralysis; CNDSS: Canadian Notifiable Disease Surveillance System;

COVID-19: coronavirus disease; CPSP: Canadian Paediatric Surveillance Program; FluCAN: InFLUenza Complications Alert Network; IMPACT: Canadian Immunization Monitoring Program, Active; NHMRC: National Health and Medical Research Council; PAEDS: Paediatric Active Enhanced Disease Surveillance; PHAC: Public Health Agency of Canada; PIMS-TS, pediatric inflammatory multisystem syndrome temporally associated with SARS-CoV-2; SARS-CoV-2: severe acute respiratory syndrome coronavirus 2.

a From 1991 to 1998 only children < 2 years of age were included.

${ }^{b}$ Investigator funding includes institutional trainee scholarships and fellowships.

of syndromic conditions, vaccine-preventable diseases (VPDs), vaccine safety monitoring, and emerging infections, are unique in the range of conditions under surveillance and potential for scalability in response to public health emergencies. We present evidence on their feasibility and value to public health surveillance, and discuss opportunities for similar platforms to enhance public health surveillance in low-, middle-, and high-income countries.

\section{History and contributions}

Both IMPACT and PAEDS arose from identified surveillance gaps in child health outcomes related to vaccine safety and VPDs. Addressing these required the establishment of national surveillance programmes due to the relatively small numbers of both paediatric patients and tertiary care centres in Canada and Australia.

\section{Canada}

The need for a hospital-based active surveillance system to reliably detect serious adverse events following immunisation (AEFIs) was recognised following detection of an increase in aseptic meningitis associated with the Urabe mumps vaccine strain in 1986-1988 by virologists at several Canadian children's hospitals [9]. Investigation of this signal, not identified by the passive system, led to replacement of the Urabe vaccine with a safer vaccine. IMPACT began in 1991 as a collaboration between Health Canada and the Canadian Paediatric Society (CPS) at five paediatric tertiary care centres in five provinces. The first surveillance targets included neurological admissions (e.g. acute flaccid paralysis (AFP), encephalopathy, seizure) and several VPDs (e.g. pertussis) (Table 1 and Supplemental Content 1) [9]. IMPACT expanded to 12 centres in eight provinces by 1999, capturing approximately $90 \%$ of paediatric tertiary care beds in Canada [9].

For 29years, IMPACT has collected epidemiological data for AEFIs and diseases that are current or future targets for vaccine prevention, demonstrating the effectiveness of new immunisation programmes, including, meningococcal conjugate, pneumococcal conjugate and varicella vaccines (Table 2) [10-12].

\section{Australia}

The PAEDS system was established in 2007 to support Australian compliance with World Health Organization (WHO) AFP surveillance standards as part of polio eradication efforts, and to conduct surveillance for varicella hospitalisations following vaccine introduction and two AEFIs potentially associated with varicella and rotavirus vaccination programmes (seizures and intussusception) (Table 1 and Supplemental Content 1) [13]. PAEDS was funded by the Australian Government as a pilot project in four paediatric hospitals in four states. PAEDS subsequently expanded to seven hospitals in six states and territories, covering around $80 \%$ of tertiary paediatric beds. The scope of PAEDS was enlarged over time to provide key evidence regarding vaccine 
TABLE 2

Major accomplishments of IMPACT since its inception, Canada, 1991-2019

Adverse events following immunisation

\begin{tabular}{|c|c|c|c|}
\hline $\begin{array}{l}\text { Infectious } \\
\text { complications of } \\
\text { vaccination }\end{array}$ & $\begin{array}{l}\text { 150-fold higher than expected incidence } \\
\text { of disseminated BCG disease among } \\
\text { Indigenous children }\end{array}$ & $\begin{array}{l}\text { Routine use of BCG limited to communities with } \\
\text { ongoing active TB disease, with negative HIV } \\
\text { screening and no risk factors for PID }\end{array}$ & $\begin{array}{l}\text { Deeks, } 2005 \\
\text { [30]; Scheifele, } \\
\text { 1998 [31] }\end{array}$ \\
\hline HHE & $67 \%$ decrease in HHE after aP vs wP & First evidence of improved safety profile of aP over wP & $\begin{array}{l}\text { Le Saux, } 2003 \\
{[32]}\end{array}$ \\
\hline Seizure & $79 \%$ decrease in seizure after aP vs wP & First evidence of improved safety profile of aP over wP & $\begin{array}{c}\text { Le Saux, } 2003 \\
{[32]}\end{array}$ \\
\hline Thrombocytopaenia & $\begin{array}{c}\text { Two of } 107 \text { children admitted with post- } \\
\text { immunisation thrombocytopaenia had } \\
\text { severe bleeding and } 93 \% \text { recovered within } \\
3 \text { months }\end{array}$ & $\begin{array}{l}\text { Largest cohort of post-immunisation } \\
\text { thrombocytopaenia }\end{array}$ & $\begin{array}{c}\text { Jadavji, } 2003 \\
\text { [33]; Sauvé, } 2010 \\
\text { [34] }\end{array}$ \\
\hline \multicolumn{4}{|c|}{ Vaccine-preventable diseases } \\
\hline $\begin{array}{l}\text { Haemophilus } \\
\text { influenzae }\end{array}$ & $\begin{array}{l}95-99 \% \text { reduction in invasive Hib cases } \\
\text { following introduction of infant Hib } \\
\text { immunisation programmes; emergence of } \\
\text { Hia in Indigenous populations; children } \\
\text { with cancer> } 5 \text { years of age are susceptible } \\
\text { to invasive Hib }\end{array}$ & $\begin{array}{c}\text { Demonstrated effectiveness of Hib vaccination } \\
\text { programmes and provided new data to support } \\
\text { development of Hia vaccine }\end{array}$ & $\begin{array}{l}\text { Scheifele, 1996; } \\
\text { McConnell, } \\
\text { 2007; Tan, 2016; } \\
\text { McNair, 2018 } \\
\text { [35-38]; }\end{array}$ \\
\hline IPD & $\begin{array}{c}48 \% \text { decrease in IPD from pre-PCV to } P C V_{13} \\
\text { era; IPD due to PCV } 13 \text { serotypes decreased } \\
\text { from } 89 \% \text { to } 34 \% \text { of cases }\end{array}$ & $\begin{array}{c}\text { Demonstrated effectiveness of PCV vaccination } \\
\text { programmes in Canada and changing epidemiology } \\
\text { of IPD }\end{array}$ & $\begin{array}{l}\text { Bettinger, } 2010 \\
\text { [10]; Bettinger, } \\
2016[39]\end{array}$ \\
\hline $\begin{array}{l}\text { Invasive } \\
\text { meningococcal } \\
\text { disease }\end{array}$ & \begin{tabular}{|} 
69\% reduction in meningococcal serogroup \\
C disease following implementation \\
of meningococcal C conjugate vaccine \\
programmes; shift to serogroup B as \\
predominant cause of IMD
\end{tabular} & $\begin{array}{c}\text { Demonstrated effectiveness of infant and adolescent } \\
\text { meningococcal C vaccination programmes and } \\
\text { estimated benefit of introducing meningococcal B } \\
\text { vaccination }\end{array}$ & $\begin{array}{l}\text { Bettinger, } \\
\text { 2013 [40]; } \\
\text { Sadaranagani, } \\
\quad 2014[11]\end{array}$ \\
\hline Pertussis & \begin{tabular}{|c|} 
Documented changing epidemiology of \\
pertussis from wP to aP eras; in aP era, \\
$76 \%$ of hospitalised cases and all 21 deaths \\
were infants $0-3$ months of age
\end{tabular} & $\begin{array}{c}\text { Demonstrated ongoing burden of pertussis in } \\
\text { young infants suggesting potential benefit of Tdap } \\
\text { vaccination during pregnancy }\end{array}$ & $\begin{array}{c}\text { Halperin, 1999; } \\
\text { Bettinger, 2007; } \\
\text { Abu Raya, 2020 } \\
{[41-43]} \\
\end{array}$ \\
\hline Rotavirus & $\begin{array}{c}83 \% \text { reduction in rotavirus hospitalisations } \\
\text { at centres with infant immunisation } \\
\text { programmes }\end{array}$ & $\begin{array}{l}\text { Contributed data to support implementation of } \\
\text { rotavirus immunisation programmes in Canada and } \\
\text { demonstrated the benefits of those programmes }\end{array}$ & $\begin{array}{l}\text { Le Saux, } 2010 \\
\text { [44]; Le Saux, } \\
2016[45]\end{array}$ \\
\hline Varicella & $\begin{array}{c}85 \% \text { reduction in varicella-related } \\
\text { hospitalisations following introduction } \\
\text { of two-dose varicella immunisation } \\
\text { programmes }\end{array}$ & $\begin{array}{l}\text { Early evidence of the effectiveness of single-dose } \\
\text { varicella immunisation programmes and added benefit } \\
\text { of second dose in reducing hospitalisation }\end{array}$ & $\begin{array}{l}\text { Law, } 2000[46] \\
\text { Tan, } 2012[12] ; \\
\text { Tan, } 2018[47]\end{array}$ \\
\hline Influenza & $\begin{array}{c}\text { Reported on relative severity of influenza B } \\
\text { vs A in children and high risk of influenza- } \\
\text { related complications in children with } \\
\text { neurodevelopmental conditions }\end{array}$ & $\begin{array}{l}\text { Provided evidence to support use of quadrivalent } \\
\text { influenza vaccines in children and addition of } \\
\text { neurological and neurodevelopmental conditions to } \\
\text { high-risk conditions for influenza vaccination }\end{array}$ & $\begin{array}{l}\text { Tran, 2012; } \\
\text { Burton, 2014; } \\
\text { Tran, 2016 } \\
\text { [48-50] }\end{array}$ \\
\hline
\end{tabular}

aP: acellular pertussis vaccine; BCG: Bacillus Calmette-Guérin vaccine; HHE: hypotonic hyporesponsive episode; Hia: Haemophilus influenzae type a; HIV: human immunodeficiency virus; IMD: invasive meningococcal disease; IMPACT: Canadian Immunization Monitoring Program, Active; IPD: invasive pneumococcal disease; PCV: pneumococcal conjugate vaccine; PID: primary immunodeficiency; TB: tuberculosis; Tdap: tetanus-diphtheria-acellular pertussis vaccine; wP: whole cell pertussis vaccine.

${ }^{a}$ For additional publications, see also: https://www.cps.ca/en/impact.

effectiveness, safety, and the impact of new vaccination programmes and to increase the population under surveillance (Table 3 and Supplemental Content 1).

\section{Network organisation and procedures}

Both IMPACT and PAEDS utilise the contribution of trained surveillance nurses at each hospital, supervised by volunteer paediatric clinicians who act as site investigators. Nurses screen hospital and emergency department admission lists for conditions under surveillance, review medical records, retrieve immunisation records, and report cases electronically on standardised case report forms to the national coordinating centre (Figure and Table 1).

The national coordinating centre submits data to national public health authorities at least quarterly for incorporation into national datasets. In Canada and Australia, centres report AEFIs directly to regional and national public health authorities.

Annual in-person meetings and standardised training have been important to maintain group cohesion and national consistency, while opportunities for data 
TABLE 3

Major accomplishments of PAEDS since its inception, Australia, 2007-2019

\begin{tabular}{|c|c|c|}
\hline $\begin{array}{l}\text { Surveillance } \\
\text { target }\end{array}$ & Major findings & Impact \\
\hline \multicolumn{3}{|l|}{ AEFIs } \\
\hline IS & $\begin{array}{c}\text { First to publish low but increased vaccine risk of IS } \\
\text { following rotavirus vaccine with new second generation } \\
\text { vaccines (RotaTeq and Rotarix); further confirmed risk } \\
\text { (vaccine attributable risk of } 6 / 100,000 \text { ) and risk-benefit } \\
\text { of vaccine programmes, and demonstrated that vaccine- } \\
\text { associated IS is not more severe than non-vaccine } \\
\text { associated IS }\end{array}$ & $\begin{array}{l}\text { Provided globally relevant safety data } \\
\text { on new vaccines, cited by WHO and } \\
\text { multiple other peak immunisation advisory } \\
\text { committees; informed risk-benefit } \\
\text { considerations regarding ongoing rotavirus } \\
\text { vaccination programmes }\end{array}$ \\
\hline $\begin{array}{l}\text { FS following } \\
\text { immunisation }\end{array}$ & $\begin{array}{l}\text { Demonstrated absence of risk of FS following MMRV } \\
\text { vaccine when used as second dose of measles- } \\
\text { containing vaccine in children aged } 12-24 \text { months, and } \\
\text { known risk of FS post-MMR dose } 1 \text { vaccine, with no risk } \\
\text { post monovalent-varicella vaccine; clinical severity } \\
\text { and developmental outcomes associated with vaccine- } \\
\text { proximate seizures in children not different to children } \\
\text { with non-vaccine proximate seizures }\end{array}$ & $\begin{array}{l}\text { Provided important safety outcome } \\
\text { monitoring relevant to NIP new vaccine } \\
\text { introduction (MMRV vaccine in 2013); } \\
\text { research into vaccine proximate seizures } \\
\text { provided new insights and reassurance for } \\
\text { public and immunisation providers }\end{array}$ \\
\hline $\begin{array}{l}\text { SANE following } \\
\text { immunisation }\end{array}$ & $\begin{array}{l}\text { Includes acute disseminated encephalomyelitis, AFP, } \\
\text { GBS and transverse myelitis; monitoring of case } \\
\text { numbers where receipt of vaccination occurred in } \\
\text { previous } 6 \text { weeks for reporting as potentially severe } \\
\text { AEFI; GBS cases post-influenza } A\left(\mathrm{H}_{1} \mathrm{~N} 1\right) \text { pdmog vaccine } \\
\text { contributed to a multinational study of influenza } \\
\mathrm{A}(\mathrm{H} 1 \mathrm{~N} 1) \text { pdmog vaccine safety }\end{array}$ & $\begin{array}{l}\text { Provided reassurance of influenza } \\
\text { (pandemic and seasonal) and other vaccine } \\
\text { safety with regard to SANEs; contributed } \\
\text { to multi-country global analysis of GBS } \\
\text { following pandemic influenza vaccine }\end{array}$ \\
\hline
\end{tabular}

Vaccine-preventable diseases

\begin{tabular}{|c|c|c|c|}
\hline $\begin{array}{l}2009 \text { influenza } \\
\text { A(H1N1)pdmo9 } \\
\text { pandemic }\end{array}$ & $\begin{array}{c}\text { Demonstrated impact of } 2009 \text { influenza } A\left(\mathrm{H}_{1} \mathrm{~N}_{1}\right) \\
\text { pdmo9 pandemic on children, extensively documenting } \\
\text { hospitalised disease fraction }\end{array}$ & $\begin{array}{l}\text { Key data source to measure impact and } \\
\text { outcomes from } 2009 \text { influenza } A\left(\mathrm{H}_{1} \mathrm{~N}_{1}\right) \\
\text { pdmog pandemic in children }\end{array}$ & $\begin{array}{l}\text { Khandaker, } 2011 \\
\text { [59]; Khandaker, } \\
2012[60] ; \\
\text { Khandaker, } 2014 \\
\text { [21] } \\
\end{array}$ \\
\hline $\begin{array}{l}\text { Seasonal } \\
\text { influenza }\end{array}$ & $\begin{array}{c}\text { Data on vaccination, including in pregnancy for infants } \\
\text { aged }\end{array}$ & $\begin{array}{c}\text { In } 2017 \text {, detailed data on extensive and } \\
\text { severe disease from influenza in children; } \\
\text { informed newly funded paediatric influenza } \\
\text { programmes in } 6 \text { states and territories }\end{array}$ & $\begin{array}{l}\text { Blyth, } 2016[61] \\
\text { Blyth, 2019 [2]; } \\
\text { Cheng, 2017a; } \\
\text { Cheng, 2017b; } \\
\text { Li-Kim Moy, 2017 } \\
\quad[62-64]\end{array}$ \\
\hline $\begin{array}{l}\text { Invasive } \\
\text { meningococcal } \\
\text { disease }\end{array}$ & $\begin{array}{l}\text { Additional detailed data to complement National } \\
\text { Notifiable Disease Surveillance System, as well as long- } \\
\text { term follow-up of outcomes and complications. }\end{array}$ & $\begin{array}{c}\text { Evidence for severe outcomes and } \\
\text { healthcare- associated costs, assisting } \\
\text { in informing policymakers regarding new } \\
\text { programmes }\end{array}$ & McRae, 2019 [58] \\
\hline $\begin{array}{l}\text { AFP } \\
\text { (poliovirus) }\end{array}$ & $\begin{array}{l}\text { Report ca } 80 \% \text { of all AFP cases as part of Australian } \\
\text { acute flaccid surveillance and enteric virus surveillance } \\
\text { programmes; post discharge follow-up and collection of } \\
\text { faecal samples for detailed testing }\end{array}$ & $\begin{array}{c}\text { Enables Australia to fulfil WHO } \\
\text { requirements for AFP surveillance; assisted } \\
\text { in documentation of new emerging } \\
\text { pathogens, e.g. EV71 and parechovirus } \\
\end{array}$ & $\begin{array}{l}\text { Paterson, } 2013[13] ; \\
\text { McRae, } 2019[58]\end{array}$ \\
\hline Pertussis & $\begin{array}{c}\text { Demonstrated severity of early infant disease, and } \\
\text { decline in hospitalised pertussis following introduction } \\
\text { of maternal vaccination }\end{array}$ & $\begin{array}{c}\text { Evidence for impact of maternal pertussis } \\
\text { vaccination in Australia }\end{array}$ & Quinn, 2018 [65] \\
\hline Varicella & $\begin{array}{c}\text { Documented decline in hospitalised varicella following } \\
\text { one-dose vaccine programme introduction; provided } \\
\text { longitudinal data on varicella genotyping over 1oyears; } \\
\text { documented rare but complex cases of vaccine virus } \\
\text { associated disease }\end{array}$ & $\begin{array}{c}\text { Key evidence of vaccine programme impact } \\
\text { and of moderate vaccine effectiveness of } \\
\text { one-dose schedule under NIP; association } \\
\text { of European clade with severity of } \\
\text { hospitalised cases }\end{array}$ & $\begin{array}{l}\text { Marshall, } 2013 \text { [66]; } \\
\text { Marshall, 2019 [67]; } \\
\text { Quinn, 2019 [53] }\end{array}$ \\
\hline \multicolumn{4}{|l|}{ Others } \\
\hline $\begin{array}{l}\text { Acute } \\
\text { encephalitis }\end{array}$ & $\begin{array}{l}\text { Provided detailed analysis on aetiology, epidemiology, } \\
\text { outcomes and healthcare needs of acute childhood } \\
\text { encephalitis, particularly relevant to communicable } \\
\text { disease control, such as influenza, EV } 71 \text {, parechovirus, } \\
\text { mycoplasma and vector borne diseases }\end{array}$ & $\begin{array}{l}\text { Work supported development of national } \\
\text { clinical guideline for investigation and } \\
\text { management, provided early detection of } \\
\text { EV } 71 \text { and parechovirus disease outbreaks, } \\
\text { and provided data for new influenza } \\
\text { vaccine programme introduction in children }\end{array}$ & $\begin{array}{l}\text { Britton, 2016a [68]; } \\
\text { Britton, 2016b [17]; } \\
\text { Britton, 2017 [69] }\end{array}$ \\
\hline iGAS & $\begin{array}{l}\text { Pilot study demonstrated clinical severity and } \\
\text { epidemiology of children hospitalised with iGAS }\end{array}$ & $\begin{array}{l}\text { Informed public health guidance and } \\
\text { consideration of iGAS to be a nationally } \\
\text { notifiable condition }\end{array}$ & $\begin{array}{l}\text { Thielemans, } 2020 \\
{[70]}\end{array}$ \\
\hline RSV & $\begin{array}{c}\text { Pilot study demonstrated clinical severity of disease in } \\
\text { hospitalised infants with RSV }\end{array}$ & $\begin{array}{c}\text { Pilot demonstrated feasibility of providing } \\
\text { detailed baseline (pre-vaccine introduction) } \\
\text { data on disease burden to inform economic } \\
\text { evaluation and contributed to WHO Global } \\
\text { RSV Surveillance Pilot study }\end{array}$ & Hirve et al, 2019 [71] \\
\hline
\end{tabular}

AEFI: adverse event following immunisation; AFP: acute flaccid paralysis; EV71: enterovirus 71; FluCAN: InFLUenza Complications Alert Network; FS: febrile seizure; GBS: Guillain-Barré syndrome; iGAS: invasive Group A streptococcal disease; IS: intussusception; MMRV: measles-mumps-rubella-varicella vaccine; NIP: national immunisation programme; PAEDS: Paediatric Active Enhanced Disease Surveillance; RSV: respiratory syncytial virus; SANE: severe acute neurological events; WHO: World Health Organization.

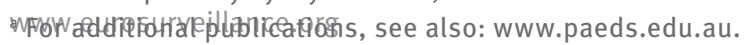


analysis, peer-reviewed publications, and improved policy and practice sustain investigator engagement.

\section{Ethical statement}

IMPACT and PAEDS surveillance is conducted and reported in line with the Declaration of Helsinki, as revised in 2013. Ethics and/or hospital approvals are in place at participating institutions (Supplemental Content 2).

\section{Funding and resources}

IMPACT is supported primarily by federal funding and managed by a non-profit organisation (CPS). This unique arrangement has allowed alternate sources of funding from provincial governments and industry to augment federally funded activities and support additional surveillance targets (e.g. rotavirus), providing stability for the network, while ensuring investigators retain independence in data collection, analysis, and publication.

PAEDS is supported by federal, state and territory government funding, and provides a platform for researchers to use the PAEDS infrastructure on a cost-recovery basis for other serious childhood conditions, such as Kawasaki disease. PAEDS has not received pharmaceutical industry funding.

Network funding, together with funding garnered to add new conditions, provides part-time support for one nurse per site, a national nurse coordinator, and data centre staff. Site investigators provide in-kind support.

\section{Hospital-based surveillance complements public health surveillance}

\section{Canada}

Public health surveillance of select VPDs is mandated by provincial and territorial governments with voluntary reporting to the Canadian Notifiable Disease Surveillance System but captures only disease onset date, sex and age. IMPACT captures additional variables for hospitalised cases including co-morbid conditions, concurrent and past infections, immunisation history, need for intensive care, and outcome at discharge. This information allows in-depth characterisation of disease burden and risk groups, as well as estimation of vaccine effectiveness, and informs cost-effectiveness analyses. Biological specimens are collected for select VPDs (e.g. Streptococcus pneumoniae, Neisseria meningitidis, rotavirus) enabling strain characterisation and monitoring for strain replacement (Table 2) [10].

IMPACT provides the only information on paediatric hospital admissions for influenza in Canada. IMPACT data are incorporated into 'FluWatch', Canada's national influenza and influenza-like illnesses surveillance system [14]. IMPACT's weekly reporting during the influenza season allows public health to assess influenza transmission and severity by person, place and time, as well as the impact and burden of influenza epidemics in real time.

The Canadian AEFI Surveillance System (CAEFISS), the national post-market vaccine safety monitoring system, relies primarily on spontaneous reporting of AEFIs to public health [15]. IMPACT contributes $>50 \%$ of serious AEFIs and 70-90\% of neurological AEFIs reported to CAEFISS [15]. In 1998, IMPACT identified an increase in disseminated Bacillus Calmette-Guérin (BCG) disease in Indigenous children with undiagnosed primary immunodeficiency, prompting changes to BCG vaccination recommendations in Canada [9].

\section{Australia}

Due to the existence of robust laboratory-based VPD surveillance through the National Notifiable Diseases Surveillance Scheme, which also captures biological specimens for select VPDs (such as those described for Canada) [16], the PAEDS network has focused on conditions where there is syndromic diagnosis (e.g. AFP, encephalitis), limited sensitivity or utilisation of laboratory tests (e.g. varicella), or where gaps in capture of immunisation status and clinical severity exist (e.g. paediatric influenza).

After 2007, PAEDS emerged as the reporting source for ca $80 \%$ of AFP cases to the Communicable Diseases Network of Australia's polio expert panel [13], resulting in Australia consistently exceeding the WHO reporting target. Enhanced studies of encephalitis via PAEDS facilitated evaluation of emerging viral infections, including enterovirus 71 and parechovirus (Table 3) [17].

Australia monitors influenza activity through a variety of complementary surveillance systems [18]. Sentinel hospital surveillance for influenza is conducted in collaboration with the InFLUenza Complications Alert Network (FluCAN) [18], which captures data from 22 sites across Australia, including seven PAEDS sites, enabling real-time tracking of a representative number of children. Paediatric influenza surveillance, including characterisation of over 1,300 paediatric hospitalisations during the 2017 influenza season, provided evidence to prompt state and territory funding of influenza vaccines for children aged 6-59 months from 2018, and inclusion on the National Immunisation Program from $2020[2,19]$.

\section{Rapid response capacity}

Both networks demonstrated capacity to respond to outbreaks of emerging diseases during the 2009 influenza $A\left(\mathrm{H}_{1} \mathrm{~N}_{1}\right)$ pdmog pandemic. IMPACT scaled up its influenza activities to continue throughout the summer (June-August) and provided one of the earliest reports on the paediatric burden of influenza $A\left(\mathrm{H}_{1} \mathrm{~N}_{1}\right)$ pdmog disease in the Northern Hemisphere during the first pandemic wave [20]. PAEDS developed questionnaires and protocols for identifying hospitalised cases of influenza rapidly, following pilot work in individual hospitals [21]. During the coronavirus disease 
Surveillance approaches of IMPACT and Australian PAEDS programmes

Team members involved

Nurses,

Paediatric investigators

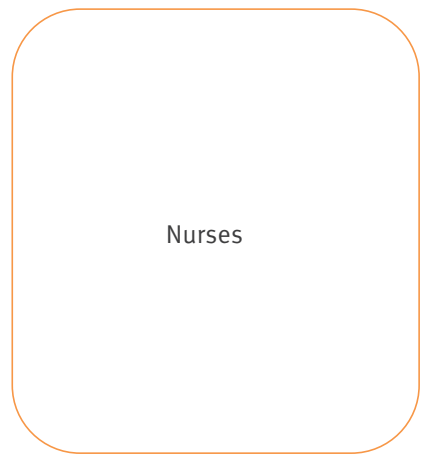

Data scrutineer,

Data manager

Data analyst, Data centre director,

Investigators,

Trainees

Data centre director,

Investigators,

Trainees
Surveillance activities

\section{Screening}

Daily admissions lists, emergency visits (PAEDS only); quarterly diagnostic code searches

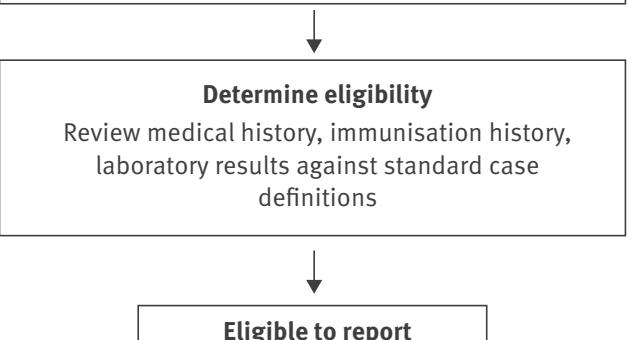

rse events following

immunisation

Report to federal, regional

public health authorities

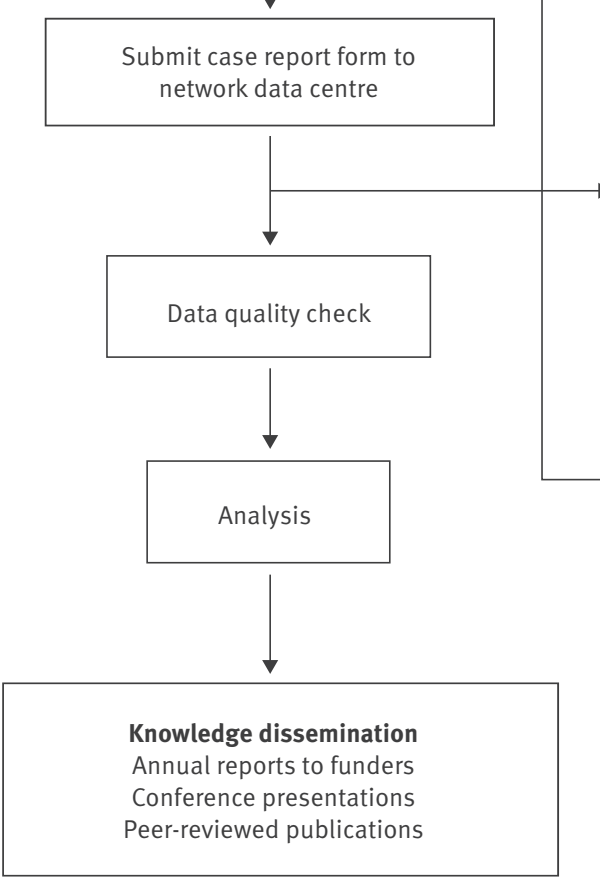

Acute flaccid paralysis (AFP)

Report to national AFP/polio surveillance programme

Vaccine preventable diseases

Ship isolates to national microbiology laboratory (IMPACT only)

IMPACT: Immunization Monitoring Program, Active; PAEDS: Paediatric Active Enhanced Disease Surveillance.

a PAEDS network requires consent for select conditions and/or for enhanced data collection.

(COVID-19) pandemic, PAEDS has been capturing data on laboratory-confirmed severe acute respiratory syndrome coronavirus 2 (SARS-CoV2) infections leading to hospitalisation or Emergency Department visit since March 2020. Surveillance for Paediatric Inflammatory Multisystem Syndrome Temporally associated with
SARS-CoV-2 (PIMS-TS; and also known as Multisystem Inflammatory Syndrome in Children (MIS-C) in the USA), a newly described inflammatory syndrome occurring during or after SARS-CoV-2 infection in children, commenced in May 2020 [22,23]. 


\section{Representativeness and ethics}

IMPACT and PAEDS networks are based in paediatric referral centres and therefore do not cover the whole population. Calculation of disease incidence has been limited to severe diseases, such as invasive meningococcal disease (IMPACT) [11] or encephalitis (PAEDS), where either most paediatric cases are admitted or transferred to an IMPACT or PAEDS centre, or the incidence is low enough to also capture cases admitted to regional or community hospitals.

To ensure complete case capture, IMPACT operates without obtaining informed consent or enrolling individual participants. This requires the data collected to be available in a hospital chart or immunisation record. Patients or caregivers are not able to add or clarify missing data.

PAEDS originally commenced surveillance requiring informed consent to allow patients to enrol for data collection. However, this resulted in non-inclusion of patients whose parents had limited spoken English or health literacy. PAEDS now operates under a national ethical framework that allows capture of a minimal deidentified dataset for all cases. Parents or caregivers can 'opt out' of their data being used and consent is still obtained to gain additional information or to opt into additional studies via parent/caregiver interview.

Another challenge faced by both systems relates to variations in capacity in the event of severe disease epidemics. During the record breaking 2017 influenza season in Australia [2], a fivefold increase in hospitalisations (cf.d with previous years) diverted nurse time away from prompt recording of other surveillance conditions.

\section{Opportunities for active hospital-based surveillance}

Hospital-based surveillance systems in high-, middle- and low-income countries, such as the Influenza Monitoring of Vaccine Effectiveness Network (I-MOVE), Healthcare-associated Infections Surveillance Network (HAl-Net) in Europe, Global Rotavirus and Invasive Bacterial Vaccine Preventable Diseases Surveillance Networks (IB-VPD), and AEFI surveillance network in the Americas have generally focused on a specific disease or syndromic target $[3-7,24,25]$. However, collectively they represent surveillance activities similar to IMPACT or PAEDS.

Population registries and linked databases have also been used to evaluate vaccine safety and effectiveness $[26,27]$. However, they are limited to high-income countries, case capture may be incomplete for certain conditions (e.g. varicella), and capacity for rapid response, detailed clinical data collection and linkage to biological specimens varies [28].

IMPACT and PAEDS have demonstrated that the same platform and similar surveillance methodologies can be applied to study a broad range of diseases and syndromes of public health importance. Conditions under surveillance can be added in response to new vaccines, vaccine safety concerns and emerging diseases, while others can be discontinued or modified. This provides efficiencies with respect to staffing time, as well as flexibility and responsiveness in the event of disease outbreaks. When emerging diseases or other conditions of concern arise, established networks like I-MOVE, IB-VPD may be well placed to rapidly expand their surveillance targets. Sharing of standard surveillance protocols may also help low- and middle-income countries expand their surveillance capacity [25]. Exploration of this concept may warrant incorporation of hospital-based surveillance networks into emerging infectious disease and AEFI surveillance plans. Capacity to activate surveillance platforms to rapidly respond to communicable disease emergencies, particularly those threatening global health security, such as the COVID-19 pandemic, is recognised as essential [29].

\section{Conclusions}

IMPACT and PAEDS have been implemented successfully to address gaps in, and add value to, public health surveillance in two countries with different needs and health systems. The adaptability of both networks to changing public health priorities in their respective countries has been critical to their success. Active hospital-based sentinel surveillance systems can leverage efficiencies gained by monitoring for more than one condition to play multiple roles in informing public health policy and responding to public health emergencies. Existing surveillance systems should consider their potential to expand conditions under surveillance, particularly as the need to evaluate health interventions and monitor for emerging infectious diseases, such as COVID-19 grows.

\section{Acknowledgments}

The authors gratefully acknowledge the expert assistance of the Monitor Liaisons (Heather Samson, Annick Audet), IMPACT nurse monitors, staff of the IMPACT Data Center (Kim Marty) and Melanie Laffin (Canadian Paediatric Society), as well as the contributions of IMPACT and PAEDS investigators to case identification, reporting and analysis of IMPACT/ PAEDS data, and review of the manuscript.

Investigators and centers participating in the IMPACT project included:

R. Morris MD, N. Bridger MD, C. Foo MD, Janeway Children's Health \& Rehabilitation Centre, St. John's, NL.

S.A. Halperin MD, K.A. Top MD, IWK Health Centre, Halifax, NS.

P. Déry MD, R. Thibeault MD, Centre Mère-Enfant de Québec, CHUL, Quebec City, PQ.

D. Moore MD, J. Papenburg MD, The Montreal Children's Hospital, Montreal, PQ.

M. Lebel MD, CHU Ste-Justine, Montreal, PQ. 
N. MacDonald, MD, N. Le Saux MD, Children's Hospital of Eastern Ontario, Ottawa, ON.

E. Wang, MD, L. Ford-Jones MD, D. Tran MD, S. Morris, MD, The Hospital for Sick Children, Toronto, ON.

B. Law MD, J. Embree MD, Winnipeg Children's Hospital, Winnipeg, MB.

B. Tan MD, A. McConnell MD, Royal University Hospital, Saskatoon, SK.

T. Jadavji MD, O.G. Vanderkooi MD, Alberta Children's Hospital, Calgary, AB.

W. Vaudry MD, Stollery Children's Hospital, Edmonton, AB.

D. Scheifele MD, J. Bettinger PhD, M. Sadarangani BM BCh DPhil, L. Sauvé MD, BC Children's Hospital, Vancouver, BC.

Investigators and centers participating in PAEDS included:

K. Macartney, N. Wood, P. Britton, R. Booy, E. Elliot and P.B. McIntyre, National Centre for Immunisation Research and Surveillance (NCIRS) and Children's Hospital Westmead, Sydney, NSW.

H. Marshall, M Gold, Women and Children's Hospital, Adelaide, South Australia.

C. Blyth and P Richmond, Princess Margaret/Perth Children's Hospital, Perth, Western Australia.

N. Crawford, Royal Children's Hospital, Melbourne, Victoria.

J. Buttery, Monash Children's Hospital, Melbourne, Victoria.

J. Francis, Royal Darwin Hospital, Darwin, Northern Territory.

J. Clark and A. Kynaston, Lady Cilento Children's Hospital, Brisbane, Queensland.

Funding statement. The Canadian Immunization Monitoring Program Active (IMPACT) is a national surveillance initiative managed by the Canadian Paediatric Society and conducted by the IMPACT network of paediatric investigators on behalf of the Public Health Agency of Canada's Centre for Immunization and Respiratory Infectious Diseases. The Paediatric Active Enhanced Disease Surveillance (PAEDS) network is coordinated by the National Centre for Immunisation Research and Surveillance (NCIRS) and receives funding from the Australian Government Department of Health, and participating state and territory departments of health in Western Australia, South Australia, Victoria, New South Wales, Queensland and Northern Territory. Funding for work on influenza is received in part from the Australian Government Department of Health, via the Influenza Complications Alert Network (FluCAN) and from NHMRC Partnership Grant (\#1113851). Funding from the NHMRC has also contributed to surveillance and studies of other PAEDS conditions.

\section{Conflict of interest}

KAT has received grants from GlaxoSmithKline and consultancy fees from Pfizer outside the submitted work. SAH has received grants from Pfizer and GlaxoSmithKline outside the submitted work. HSM is an investigator on vaccine trials sponsored by industry. Her institution receives funding for investigator led research (GSK, Pfizer, Sanofi-Pasteur). HSM acknowledges support from the National Health and Medical Research Council NHMRC (APP1155066). CCB acknowledges support from the NHMRC (APP1111596). The other authors have no disclosures.

\section{Authors' contributions}

KAT: Contributed to case identification and reporting for IMPACT, reviewed the literature, developed the structure of this perspective, co-wrote the first manuscript draft, revised the manuscript.

KM: Oversaw PAEDS programme, including case identification, reporting and analysis, conceived of the idea for this perspective, contributed to literature review, contributed to developing the structure of this perspective, co-wrote the first manuscript draft, reviewed and edited the manuscript.

JAB: Oversaw data collection, management and analysis for IMPACT, contributed to structuring this perspective, contributed to the first manuscript draft, reviewed and edited the manuscript.

BT: Contributed to case identification and reporting for IMPACT, contributed to the first manuscript draft, reviewed and edited the manuscript.

CCB: Contributed to case identification and reporting for PAEDS, reviewed and edited the manuscript.

HSM: Contributed to case identification and reporting for PAEDS, reviewed and edited the manuscript.

WV: Oversaw IMPACT programme, including case identification, reporting and analysis, contributed to developing the structure of this perspective, reviewed and edited the manuscript.

SAH: Oversaw IMPACT programme, including case identification, reporting and analysis, contributed to developing the structure of this perspective, reviewed and edited the manuscript.

PM: Oversaw PAEDS programme, including case identification, reporting and analysis, contributed to developing the structure of this perspective, contributed to the first manuscript draft, reviewed and edited the manuscript.

\section{References}

1. Thomson G, Nicoll A. Responding to new severe diseases--the case for routine hospital surveillance and clinical networks in Europe. Euro Surveill. 2010;15(49):15. https://doi.org/10.2807/ ese.15.49.19745-en PMID: 21163183

2. Blyth CC, Macartney KK, MCRae J, Clark JE, Marshall HS, Buttery J, et al. , Paediatric Active Enhanced Disease Surveillance (PAEDS), Influenza Complications Alert Network (FluCAN) Collaboration. Influenza Epidemiology, Vaccine Coverage and Vaccine Effectiveness in Children Admitted to Sentinel Australian Hospitals in 2017: Results from the PAEDS-FluCAN Collaboration. Clin Infect Dis. 2019;68(6):940-8. https://doi.org/10.1093/cid/ciy597 PMID: 30137244

3. European Centre for Disease Prevention and Control (ECDC). Healthcare-associated Infections Surveillance Network (HAI-Net). Stockholm: ECDC. [Accessed 24 Jun 2020] Available from: https://ecdc.europa.eu/en/about-us/ partnerships-and-networks/disease-and-laboratory-networks/ hai-net

4. Kissling E, Rondy M, I-MOVE/I-MOVE+ study team. Early 2016/17 vaccine effectiveness estimates against influenza $\mathrm{A}\left(\mathrm{H}_{3} \mathrm{~N}_{2}\right)$ : I-MOVE multicentre case control studies at primary care and hospital levels in Europe. Euro Surveill. 2017;22(7):30464. https://doi.org/10.2807/1560-7917. ES.2017.22.7.30464 PMID: 28230524

5. Hasan AZ, Saha S, Saha SK, Sahakyan G, Grigoryan S, Mwenda JM, et al. . Using pneumococcal and rotavirus surveillance in vaccine decision-making: A series of case studies in Bangladesh, Armenia and the Gambia. 
Vaccine. 2018;36(32);4939-43. https://doi.org/10.1016/j. vaccine.2018.06.001 PMID: 30037484

6. Tate JE, Mwenda JM, Armah G, Jani B, Omore R, Ademe A, et al. , African Intussusception Surveillance Network. Evaluation of Intussusception after Monovalent Rotavirus Vaccination in Africa. N Engl J Med. 2018;378(16):1521-8. https://doi. org/10.1056/NEJMoa1713909 PMID: 29669224

7. Bravo-Alcántara P, Pérez-Vilar S, Molina-León HF, Sturkenboom M, Black S, Zuber PLF, et al. , L.A.N.V.A.P. (Latin American Network for VAccine Pharmacovigilance). Building capacity for active surveillance of vaccine adverse events in the Americas: A hospital-based multi-country network. Vaccine. 2018;36(3):363-70. https://doi.org/10.1016/j. vaccine.2017.04.069 PMID: 28803714

8. Merdrignac L, Tozzi AE, Belchior E, Jané M, Krizova P, Garcia Cenoz M, et al. Pilot season of PERTINENT, a novel sentinel system to measure the burden of pertussis in hospitalised infants in EU/EEA. In: Proceedings of ESPID 2017 conference; 2017 May 23-27; Madrid, Spain. ESP17-1188. Available from: http://espid2017.kenes.com/Documents/ESPID17\%20 abstracts.pdf

9. Scheifele DW, Halperin SA, CPS/Health Canada, Immunization Monitoring Program, Active (IMPACT). Immunization Monitoring Program, Active: a model of active surveillance of vaccine safety. Semin Pediatr Infect Dis. 2003;14(3):213-9. https://doi. org/10.1016/S1045-1870(03)00036-0 PMID: 12913834

10. Bettinger JA, Scheifele DW, Kellner JD, Halperin SA, Vaudry W, Law B, et al. , Canadian Immunization Monitoring Program, Active (IMPACT). The effect of routine vaccination on invasive pneumococcal infections in Canadian children, Immunization Monitoring Program, Active 2000-2007. Vaccine. 2010;28(9):2130-6. https://doi.org/10.1016/j. vaccine.2009.12.026 PMID: 20044050

11. Sadarangani M, Scheifele DW, Halperin SA, Vaudry W, Le Saux $\mathrm{N}$, Tsang R, et al. , investigators of the Canadian Immunization Monitoring Program, ACTive (IMPACT). The impact of the meningococcal serogroup $C$ conjugate vaccine in Canada between 2002 and 2012. Clin Infect Dis. 2014;59(9):1208-15. https://doi.org/10.1093/cid/ciu597 PMID: 25069868

12. Tan B, Bettinger J, McConnell A, Scheifele D, Halperin S, Vaudry W, et al. , Members of the Canadian Immunization Monitoring Program, Active (IMPACT). The effect of funded varicella immunization programs on varicella-related hospitalizations in IMPACT centers, Canada, 2000-2008. Pediatr Infect Dis J. 2012;31(9):956-63. https://doi.org/10.1097/ INF.obo13e31826occ4d PMID: 22647896

13. Paterson BJ, Durrheim DN. Review of Australia's polio surveillance. Commun Dis Intell Q Rep. 2013;37(2):E149-55. PMID: 24168089

14. Government of Canada. Fluwatch. 2018; updated August 31 2018; [Accessed 7 Sep 2018]. Available from. https://www. canada.ca/en/public-health/services/diseases/flu-influenza/ influenza-surveillance/about-fluwatch.html

15. Ahmadipour N, Watkins K, Fréchette M, Coulby C, Anyoti H, Johnson K. Vaccine safety surveillance in Canada: Reports to CAEFISS, 2013-2016. Can Commun Dis Rep. 2018;44(9):206-14. https://doi.org/10.14745/ccdr.v44ioga04 PMID: 31015811

16. Gibney KB, Cheng AC, Hall R, Leder K. Sociodemographic and geographical inequalities in notifiable infectious diseases in Australia: a retrospective analysis of 21 years of national disease surveillance data. Lancet Infect Dis. 2017;17(1):8697. https://doi.org/10.1016/S1473-3099(16)30309-7 PMID: 27789179

17. Britton PN, Dale RC, Nissen MD, Crawford N, Elliott E, Macartney K, et al. , PAEDS-ACE Investigators. Parechovirus Encephalitis and Neurodevelopmental Outcomes. Pediatrics. 2016;137(2):e20152848. https://doi.org/10.1542/peds.20152848 PMID: 26791970

18. Sullivan SGP, Raupach KJ, Franklin LJ, Bareja C, de Kluyver R and the National Influenza Surveillance Committee, for the Communicable Diseases Network Australia. A summary of influenza surveillance systems in Australia, 2015. Camberra: Department of Health. Available from: https://www1.health. gov.au/internet/main/publishing.nsf/Content/cda-surveilozflu-flucurr.htm/\$File/Influenza-Surveillance-Systems-Paper. pdf

19. Beard FH, Hendry AJ, Macartney K. Early success with room for improvement: influenza vaccination of young Australian children. Med J Aust. 2019;210(11):484-486.e1. https://doi. org/10.5694/mja2.50141 PMID: 31063595

20. Bettinger JA, Sauvé LJ, Scheifele DW, Moore D, Vaudry W, Tran $D$, et al. Pandemic influenza in Canadian children: a summary of hospitalized pediatric cases. Vaccine. 2010;28(18):31804. https://doi.org/10.1016/j.vaccine.2010.02.044 PMID: 20189488
21. Khandaker G, Zurynski Y, Ridley G, Buttery J, Marshall H, Richmond PC, et al. Clinical epidemiology and predictors of outcome in children hospitalised with influenza $A\left(\mathrm{H}_{1} \mathrm{~N}_{1}\right)$ pdmog in 2009: a prospective national study. Influenza Other Respir Viruses. 2014;8(6):636-45. https://doi.org/10.1111/irv.12286 PMID: 25263176

22. Whittaker E, Bamford A, Kenny J, Kaforou M, Jones CE, Shah P, et al. , PIMS-TS Study Group and EUCLIDS and PERFORM Consortia. Clinical Characteristics of 58 Children With a Pediatric Inflammatory Multisystem Syndrome Temporally Associated With SARS-CoV-2. JAMA. 2020;e2010369. https:// doi.org/10.1001/jama.2020.10369 PMID: 32511692

23. Paediatric Active Enhanced Disease Surveillance (PAEDS). COVID-19, Kawasaki Disease (KD) and PIMS-TS in children. PAEDS. 15 May 2020. Available from: http://www.paeds.org. au/covid-19-kawasaki-disease-kd-and-pims-ts-children

24. Invasive bacterial vaccine preventable disease sentinel hospital surveillance network: summary of a strategic review and next steps, 2008-2014. Wkly Epidemiol Rec. 2014;89(49):545-50. PMID: 25485342

25. Mursalova N, Shugayev N, Suleymanova J, Daniels DS, Wasley A, Cohen AL, et al. Rotavirus gastroenteritis surveillance in Azerbaijan, 2011-2016. Vaccine. 2018;36(51):7790-3. https:// doi.org/10.1016/j.vaccine.2018.02.045 PMID: 29784471

26. Hviid A, Hansen JV, Frisch M, Melbye M. Measles, Mumps, Rubella Vaccination and Autism: A Nationwide Cohort Study. Ann Intern Med. 2019;170(8):513-20. https://doi.org/10.7326/ M18-2101 PMID: 30831578

27. Baum U, Kulathinal S, Auranen K, Nohynek H. Effectiveness of two influenza vaccines in nationwide cohorts of Finnish twoyear-old children in the seasons 2015/16-2017/18. Clin Infect Dis. 2020;ciaa050. https://doi.org/10.1093/cid/ciaa050 PMID: 31955204

28. Glode Helmuth I, Broccia MD, Glenthøj JP, Harder K, Jensen $\mathrm{L}$, von Linstow ML, et al. Children Hospitalized with Varicella in Denmark: Sensitivity of the National Patient Register. Pediatr Infect Dis J. 2017;36(1):31-5. https://doi.org/10.1097/ INF.0000000000001347 PMID: 27749656

29. Gostin LO, Tomori O, Wibulpolprasert S, Jha AK, Frenk J, Moon S, et al. Toward a Common Secure Future: Four Global Commissions in the Wake of Ebola. PLoS Med. 2016;13(5):e1002042. https://doi.org/10.1371/journal. pmed.1002042 PMID: 27195954

30. Deeks SL, Clark M, Scheifele DW, Law BJ, Dawar M, Ahmadipour N, et al. Serious adverse events associated with bacille Calmette-Guérin vaccine in Canada. Pediatr Infect Dis J. 2005;24(6):538-41. https://doi.org/10.1097/01. inf.0000164769.22033.2C PMID: 15933565

31. Scheifele D, Law B, Jadavji T. Disseminated bacille CalmetteGuérin infection: three recent Canadian cases. IMPACT. Immunization Monitoring Program, Active. Can Commun Dis Rep. 1998;24(9):69-72, discussion 73-5. PMID: 9611413

32. Le Saux N, Barrowman NJ, Moore DL, Whiting S, Scheifele D, Halperin S, Canadian Paediatric Society/ Health Canada Immunization Monitoring Program-Active (IMPACT). Decrease in hospital admissions for febrile seizures and reports of hypotonic-hyporesponsive episodes presenting to hospital emergency departments since switching to acellular pertussis vaccine in Canada: a report from IMPACT. Pediatrics. 2003;112(5):e348. https://doi.org/10.1542/peds.112.5.e348 PMID: 14595075

33. Jadavji T, Scheifele D, Halperin S, Canadian Paediatric Society/Health Cananda Immunization Monitoring Program. Thrombocytopenia after immunization of Canadian children, 1992 to 2001. Pediatr Infect Dis J. 2003;22(2):119-22. https:// doi.org/10.1097/01.inf.0000048961.08486.d1 PMID: 12586974

34. Sauvé LJ, Bettinger J, Scheifele D, Halperin S, Vaudry W, Law $B$, Canadian Immunization Monitoring Program, and Active (IMPACT). Postvaccination thrombocytopenia in Canada. Pediatr Infect Dis J. 2010;29(6):559-61. PMID: 20160658

35. Scheifele DW. Recent trends in pediatric Haemophilus influenzae type B infections in Canada. Immunization Monitoring Program, Active (IMPACT) of the Canadian Paediatric Society and the Laboratory Centre for Disease Control. CMAJ. 1996;154(7):1041-7. PMID: 8625025

36. McConnell A, Tan B, Scheifele D, Halperin S, Vaudry W, Law $B$, et al. , of The Canadian Immunization Monitoring Program, ACTive (IMPACT). Invasive infections caused by Haemophilus influenzae serotypes in twelve Canadian IMPACT centers, 1996-2001. Pediatr Infect Dis J. 2007;26(11):1025-31. https:// doi.org/10.1097/INF.ob013e31812f4f5b PMID: 17984810

37. Tan B. The epidemiology of invasive diseases caused by Haemophilus influenzae type $A$ : A report from the Canadian Immunization Monitoring Program ACTive (IMPACT). Canadian Immunization Conference; Ottawa, Ontario2016. 
38. McNair J, Smith A, Bettinger JA, Vaudry W, Tan B, Desai S, et al. , Canadian Immunization Monitoring Program Active (IMPACT) Investigators. Invasive Haemophilus influenzae Type $B$ infections in children with cancer in the era of infant Hib immunization programs (1991-2014): A Report From the Canadian Immunization Monitoring Program Active. Pediatr Infect Dis J. 2018;37(7):726-8. https://doi.org/10.1097/ INF.0000000000001850 PMID: 29200182

39. Bettinger J, Scheifele D, Kellner J, Le Saux N, Embree J, Vanderkooi 0, et al. Invasive pneumococcal disease in Canadian children, 2000-2014: The Canadian Immunization Monitoring Program, Active. Paediatr Child Health. 2016;21:274.

40. Bettinger JA, Scheifele DW, Halperin SA, Vaudry W, Findlow J, Borrow R, et al. , members of the Canadian Immunization Monitoring Program, Active (IMPACT). Diversity of Canadian meningococcal serogroup $B$ isolates and estimated coverage by an investigational meningococcal serogroup $B$ vaccine (4CMenB). Vaccine. 2013;32(1):124-30. https://doi. org/10.1016/j.vaccine.2013.03.063 PMID: 23588089

41. Halperin SA, Wang EE, Law B, Mills E, Morris R, Déry P, et al. Epidemiological features of pertussis in hospitalized patients in Canada, 1991-1997: report of the Immunization Monitoring Program--Active (IMPACT). Clin Infect Dis. 1999;28(6):1238-43. https://doi.org/10.1086/514792 PMID: 10451159

42. Bettinger JA, Halperin SA, De Serres G, Scheifele DW, Tam T. The effect of changing from whole-cell to acellular pertussis vaccine on the epidemiology of hospitalized children with pertussis in Canada. Pediatr Infect Dis J. 2007;26(1):31-5. https://doi.org/10.1097/01.inf.0000247055.81541.04 PMID: 17195702

43. Abu-Raya B, Bettinger JA, Vanderkooi OG, Vaudry W, Halperin SA, Sadarangani M, et al. Burden of children hospitalized with pertussis in Canada in the acellular pertussis vaccine era, 1999-2015. J Pediatric Infect Dis Soc. 2020;9(2):118-27. https://doi.org/10.1093/jpids/piy128 PMID: 30535079

44. Le Saux N, Bettinger JA, Halperin SA, Vaudry W, Scheifele DW, Canadian Immunization Monitoring Program, Active (IMPACT). Substantial morbidity for hospitalized children with community-acquired rotavirus infections: 20052007 IMPACT surveillance in Canadian hospitals. Pediatr Infect Dis J. 2010;29(9):879-82. https://doi.org/10.1097/ INF.obo13e3181e20c94 PMID: 20467353

45. Le Saux N, Halperin S, Scheifele D, Vaudry W, Bettinger JA, on behalf of Immunization Monitoring Program ACTive (IMPACT) investigators. Rotavirus hospitalizations in Canada: A decade of surveillance. Canadian Immunization Conference 2016; Ottawa, Ontario, 2016.

46. Law B, MacDonald N, Halperin S, Scheifele D, Déry P, Jadavji T, et al. The Immunization Monitoring Program Active (IMPACT) prospective five year study of Canadian children hospitalized for chickenpox or an associated complication. Pediatr Infect Dis J. 2000;19(11):1053-9. https://doi.org/10.1097/00006454200011000-00005 PMID: 11099085

47. Tan B, McConnell A, Thibeault R, Jadavji T, Reyes Domingo $\mathrm{F}$, Samson $\mathrm{H}$, Severini A, et al. Varicella hospitalizations in IMPACT (Immunization Monitoring Program, ACTive) centers after introduction of 1 - and 2 - dose varicella vaccination programs between 2000 and 2015. Canadian Paediatric Society Annual Meeting; Quebec City, QC 2018.

48. Tran D, Vaudry W, Moore DL, Bettinger JA, Halperin SA, Scheifele DW, et al. , IMPACT investigators. Comparison of children hospitalized with seasonal versus pandemic influenza A, 2004-2009. Pediatrics. 2012;130(3):397-406. https://doi. org/10.1542/peds.2011-3216 PMID: 22931901

49. Burton C, Vaudry W, Moore D, Bettinger JA, Tran D, Halperin SA, et al. , IMPACT investigators. Burden of seasonal influenza in children with neurodevelopmental conditions. Pediatr Infect Dis J. 2014;33(7):710-4. https://doi.org/10.1097/ INF.0000000000000272 PMID: 24918745

50. Tran D, Vaudry W, Moore D, Bettinger JA, Halperin SA, Scheifele DW, et al. , members of the Canadian Immunization Monitoring Program Active. Hospitalization for Influenza A Versus B. Pediatrics. 2016;138(3):e20154643. https://doi.org/10.1542/ peds.2015-4643 PMID: 27535144

51. Buttery JP, Danchin MH, Lee KJ, Carlin JB, Mclntyre PB, Elliott EJ, et al. , PAEDS/APSU Study Group. Intussusception following rotavirus vaccine administration: post-marketing surveillance in the National Immunization Program in Australia. Vaccine. 2011;29(16):3061-6. https://doi.org/10.1016/j. vaccine.2011.01.088 PMID: 21316503

52. Carlin JB, Macartney KK, Lee KJ, Quinn HE, Buttery J, Lopert R, et al. Intussusception risk and disease prevention associated with rotavirus vaccines in Australia's National Immunization Program. Clin Infect Dis. 2013;57(10):1427-34. https://doi. org/10.1093/cid/cit520 PMID: 23964090
53. Quinn HE, Gidding HF, Marshall HS, Booy R, Elliott EJ, Richmond P, et al., PAEDS (Paediatric Active Enhanced Disease Surveillance) Network. Varicella vaccine effectiveness over 10 years in Australia; moderate protection from 1-dose program. J Infect. 2019;78(3):220-5. https://doi.org/10.1016/j. jinf.2018.11.009 PMID: 30528868

54. Macartney KK, Gidding HF, Trinh L, Wang H, McRae J, Crawford N, et al. , PAEDS (Paediatric Active Enhanced Disease Surveillance) Network. Febrile seizures following measles and varicella vaccines in young children in Australia. Vaccine. 2015;33(11):1412-7. https://doi.org/10.1016/j. vaccine.2014.10.071 PMID: 25444797

55. Macartney K, Gidding HF, Trinh L, Wang H, Dey A, Hull B, et al. , Paediatric Active Enhanced Disease Surveillance Network. Evaluation of Combination Measles-MumpsRubella-Varicella Vaccine Introduction in Australia. JAMA Pediatr. 2017;171(10):992-8. https://doi.org/10.1001/ jamapediatrics.2017.1965 PMID: 28806450

56. Deng L, Gidding HF, Crawford N, Buttery J, Gold M, Richmond $P$, et al. Post vaccination febrile seizure severity and outcome. Pediatrics. 2019;143(5):e20182120. https://doi.org/10.1542/ peds.2018-2120

57. Dodd CN, Romio SA, Black S, Vellozzi C, Andrews N, Sturkenboom M, et al., Global H1N1 GBS Consortium. International collaboration to assess the risk of Guillain Barré Syndrome following Influenza A ( $\left.\mathrm{H}_{1} \mathrm{~N}_{1}\right) 2009$ monovalent vaccines. Vaccine. 2013;31(40):4448-58. https://doi. org/10.1016/j.vaccine.2013.06.032 PMID: 23770307

58. McRae JE, Quinn HE, Saravanos GL, McMinn A, Britton PN, Wood N, et al. Paediatric Active Enhanced Disease Surveillance (PAEDS) annual report 2016: Prospective hospital-based surveillance for serious paediatric conditions. Commun Dis Intell (2018). 2019;43:43. https://doi.org/10.33321/ cdi.2019.43.5 PMID: 30727704

59. Khandaker G, Lester-Smith D, Zurynski Y, Elliott EJ, Booy R. Pandemic ( $\left.\mathrm{H}_{1} \mathrm{~N}_{1}\right) 2009$ and seasonal influenza $A$ $\left(\mathrm{H}_{3} \mathrm{~N}_{2}\right)$ in children's hospital, Australia. Emerg Infect Dis. 2011;17(10):1960-2. https://doi.org/10.3201/eid1710.101670 PMID: 22000384

60. Khandaker G, Zurynski Y, Buttery J, Marshall H, Richmond PC, Dale RC, et al. Neurologic complications of influenza $A\left(\mathrm{H}_{1} \mathrm{~N}_{1}\right)$ pdmo9: surveillance in 6 pediatric hospitals. Neurology. 2012;79(14):1474-81. https://doi.org/10.1212/ WNL.obo13e31826d5ea7 PMID: 22993280

61. Blyth CC, Macartney KK, Hewagama S, Senenayake S, Friedman ND, Simpson G, et al. Influenza epidemiology, vaccine coverage and vaccine effectiveness in children admitted to sentinel Australian hospitals in 2014: the Influenza Complications Alert Network (FluCAN). Euro Surveill. 2016;21(30):30301. https://doi.org/10.2807/1560-7917. ES.2016.21.30.30301 PMID: 27494798

62. Cheng AC, Holmes M, Dwyer DE, Irving L, Korman T, Senenayake $S$, et al. Influenza epidemiology in patients admitted to sentinel Australian hospitals in 2016: the Influenza Complications Alert Network (FluCAN). Commun Dis Intell Q Rep. 2017;41(4):E337-47. PMID: 29864387

63. Cheng AC, Macartney KK, Waterer GW, Kotsimbos T, Kelly PM, Blyth CC, et al. , Influenza Complications Alert Network (FluCAN) Investigators. Repeated vaccination does not appear to impact upon influenza vaccine effectiveness against hospitalization with confirmed influenza. Clin Infect Dis 2017;64(11):1564-72. https://doi.org/10.1093/cid/cix209 PMID: 28329167

64. Li-Kim-Moy J, Yin JK, Blyth CC, Kesson A, Booy R, Cheng $A C$, et al. Influenza hospitalizations in Australian children. Epidemiol Infect. 2017;145(7):1451-60. https://doi.org/10.1017/ So950268816003381 PMID: 28162130

65. Quinn HE, Comeau J, Marshall H, Elliott E, Crawford N, Blyth $C$, et al. Effectiveness of maternal vaccination among infants aged $<6$ months hospitalised with pertussis. Public Health Association Australia 16th National Immunisation Conference 2018; Adelaide 2018.

66. Marshall HS, Mclntyre P, Richmond P, Buttery JP, Royle JA, Gold MS, et al. Changes in patterns of hospitalized children with varicella and of associated varicella genotypes after introduction of varicella vaccine in Australia. Pediatr Infect Dis J. 2013;32(5):530-7. https://doi.org/10.1097/ INF.ob013e31827e92b7 PMID: 23249914

67. Marshall HS, Clarke M, Heath C, Quinn H, Richmond PC, Crawford N, et al. , PAEDS Investigators. Severe and complicated varicella and associated genotypes 10 years after introduction of a one dose varicella vaccine program. J Infect Dis. 2019;219(3):391-9. https://doi.org/10.1093/infdis/jiy518 PMID: 30184182

68. Britton PN, Dale RC, Elliott E, Festa M, Macartney K, Booy R, et al. Pilot surveillance for childhood encephalitis in Australia using the Paediatric Active Enhanced Disease Surveillance 
(PAEDS) network. Epidemiol Infect. 2016;144(10):2117-27. PMID: 26916674

69. Britton PN, Blyth CC, Macartney K, Dale RC, Li-Kim-Moy J, Khandaker G, et al. , Australian Childhood Encephalitis (ACE) Study Investigators, Influenza Complications Alert Network (FluCAN) Investigators, and Paediatric Active Enhanced Disease Surveillance (PAEDS) Network. The spectrum and burden of influenza-associated neurological disease in children: combined encephalitis and influenza sentinel site surveillance from Australia, 2013-2015. Clin Infect Dis. 2017;65(4):653-60. https://doi.org/10.1093/cid/cix412 PMID: 29017268

70. Thielemans E, Oliver J, McMinn A, Baker C, Britton PN, Clark J, et al. Clinical Description and Outcomes of Australian children with invasive Group A Streptococcal disease. Pediatr Infect Dis J. 2020;39(5):379-84. https://doi.org/10.1097/ INF.0000000000002596 PMID: 32091492

71. Hirve S, Crawford N, Palekar R, Zhang W, Bancej C, Barr I, et al. , WHO RSV surveillance Group. Clinical characteristics, predictors, and performance of case definition-Interim results from the WHO global respiratory syncytial virus surveillance pilot. Influenza Other Respir Viruses. 2019;irv.12688. https:// doi.org/10.1111/irv.12688 PMID: 31670892

\section{License, supplementary material and copyright}

This is an open-access article distributed under the terms of the Creative Commons Attribution (CC BY 4.0) Licence. You may share and adapt the material, but must give appropriate credit to the source, provide a link to the licence and indicate if changes were made.

Any supplementary material referenced in the article can be found in the online version.

This article is copyright of the authors or their affiliated institutions, 2020. 